\title{
Reactions inside nanoscale protein cages
}

\author{
Saskia A. Bode, ${ }^{a}$ Inge J. Minten, ${ }^{a}$ Roeland J. M. Nolte ${ }^{a}$ and Jeroen J. L. M. Cornelissen ${ }^{* a b}$ \\ Received 21st December 2010, Accepted 7th February 2011 \\ DOI: 10.1039/c0nr01013h
}

\begin{abstract}
Chemical reactions are traditionally carried out in bulk solution, but in nature confined spaces, like cell organelles, are used to obtain control in time and space of conversion. One way of studying these reactions in confinement is the development and use of small reaction vessels dispersed in solution, such as vesicles and micelles. The utilization of protein cages as reaction vessels is a relatively new field and very promising as these capsules are inherently monodisperse, in that way providing uniform reaction conditions, and are readily accessible to both chemical and genetic modifications. In this review, we aim to give an overview of the different kinds of nanoscale protein cages that have been employed as confined reaction spaces.
\end{abstract}

\section{Introduction}

Reactions in confined space are currently gaining much interest, because these are expected to lead to unique characteristics of the products and also to have a drastic impact on reaction kinetics. ${ }^{1,2}$ By performing enzymatic reactions in a confined space, scientists try to mimic the way in which enzymes react in nature. Compartmentalization occurs inside cells to create small separate locations with a specialized function, in which high

${ }^{a}$ Institute for Molecules and Materials, Radboud University Nijmegen, Heyendaalseweg 135, 6525 AJ Nijmegen, The Netherlands. E-mail: j.j.l. m.cornelissen@utwente.nl; Fax: +3153 4894645; Tel: +31534894380

${ }^{b}$ Laboratory for Biomolecular Nanotechnology, MESA+ Institute for Nanotechnology, University of Twente, PO Box 217, NL-7500 AE Enschede, The Netherlands concentrations of specific enzymes can be realized, and to achieve control over the order in which the enzymes react. Often the product of one reaction functions as a catalyst or substrate for the following one. ${ }^{3}$ This might significantly decrease formation of side-products and increase reaction rates. The study of enzymes in confined spaces is therefore of crucial importance to gain insight into the complex processes of the cell, for the development of improved catalytic systems, for the synthesis of new products, etc. Many studies concerning the encapsulation of enzymes by using various spherical particles, such as liposomes, polymersomes, and other aggregates, have been reported. ${ }^{4-7}$ However, due to their polydisperse nature, reaction conditions vary considerably from particle to particle. Protein cages are very monodisperse, and can potentially be of great use for the study of enzymatic reactions in confined space. The application of protein

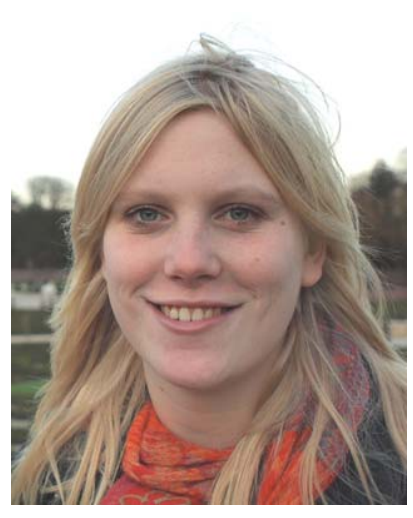

Saskia A. Bode
Saskia Bode obtained her BSc degree in Molecular Life Sciences in 2009 at the Radboud University Nijmegen, the Netherlands and continued her studies to obtain a masters degree with a traineeship in the group of Prof. Jeroen Cornelissen and Prof. Roeland Nolte. This research focused on the interactions of the cowpea chlorotic mottle virus with negatively charged polymers. She is currently in the second year of her MSc studies, investigating the internalization mechanisms of cell-penetrating peptides in the group of Prof. Solange Lavielle at University Pierre and Marie Curie, Paris.

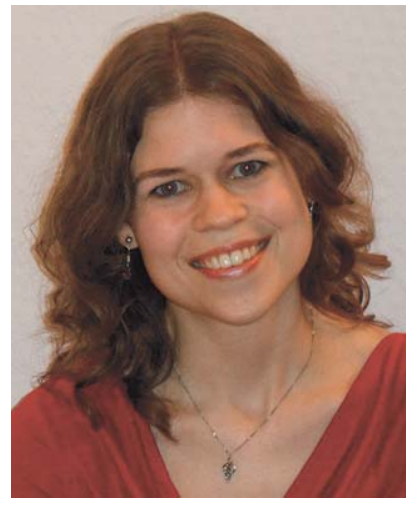

Inge J. Minten
Inge Minten studied Molecular Life Sciences at the Radboud University Nijmegen in the Netherlands. She received her master's degree in 2006 after traineeships in the bio-organic chemistry group of Prof. Jan van Hest and the molecular design \& informatics group of Prof. Jacob de Vlieg, at Organon in Oss. She obtained her PhD in 2011 based on research carried out in the group of Prof. Jeroen Cornelissen and Prof. Roeland Nolte. This work concerned the use of the cowpea chlorotic mottle virus as a multi-enzyme nanoreactor. At present Inge Minten is working as a post-doc at DSM in Geleen. 
cages for enzymatic reactions is a relatively new field and only recently a few examples have been reported..$^{8-12}$ In this way, these materials might even be considered as simple mimics of protein based organelles found in bacteria.

Protein cages do not only have potential applications in the study of enzymatic reactions. In the past 20 years, the field of biomineralization has demonstrated that protein cages can also be used for the formation of highly monodisperse nanoparticles. In these processes the protein cage has different functions: it provides a constrained environment providing the proper conditions for the formation of highly monodisperse nanoparticles, it prevents aggregation of the formed nanoparticles, and in many cases it induces the mineralization reaction. It does so by providing the molecular interactions between the organic and inorganic phases that are crucial for the biomineralization process. ${ }^{13}$ An example is the well-defined interior cavity of protein cages like ferritin, which is used as a nanoreactor for the synthesis of inorganic nanoparticles. ${ }^{15}$ Also viral cages and even bacterial multi-enzyme complexes have been used for this purpose. ${ }^{13}$ These systems have a high charge density at certain regions in their inner cavity, which can act as nucleation sites for the mineralization. Using these strategies, monodisperse single crystal nanoparticles can be grown inside capsids and cages. In addition the protein shell itself can be modified to add extra functionality to the nanoparticles.

\section{Protein cages}

In nature, several proteins exist that carry or store metal ions and minerals. These proteins can often be used as hosts for biomineralization reactions. A well known and intensively studied example is the iron-storage protein ferritin, which is discussed below. Other proteins that are also being used for these purposes are bacterial $D N A$ binding proteins from starved cells (Dps) ferritin and the small heat shock protein (sHsp).

\section{Ferritin}

Ferritins are a class of non-haem iron storage proteins that are produced by animals, plants, fungi, and bacteria. ${ }^{16}$ In nature, iron is stored within the multi-subunit protein shell as a hydrous ferric oxide nanoparticle. ${ }^{17}$ Ferritins can withstand high temperatures $\left(85^{\circ} \mathrm{C}\right)$ and high $\mathrm{pH}$ values (8.5-9.0) which make them attractive for use in covalent and non-covalent synthesis. ${ }^{18}$

Iron-free ferritin (apoferritin or holo-ferritin) is a protein complex of approximately $450 \mathrm{kDa} .{ }^{19}$ It consists of 24 polypeptide subunits which assemble into a hollow sphere with outer and inner diameters of $12 \mathrm{~nm}$ and $8 \mathrm{~nm}$, respectively (Fig. 1). ${ }^{20}$
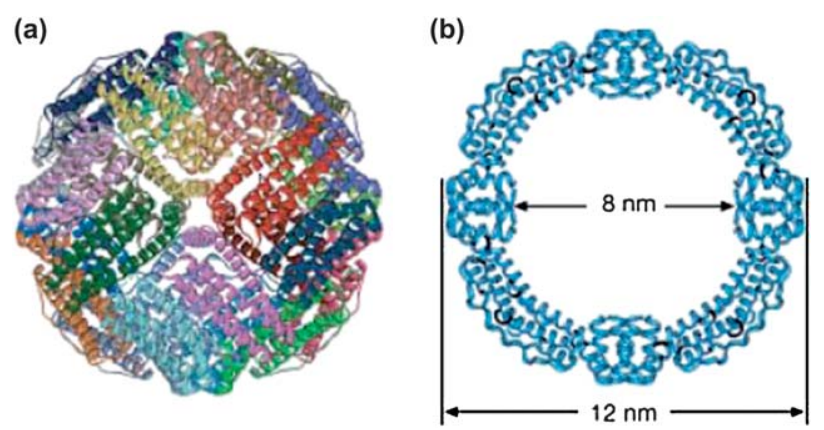

Fig. 1 Schematic representation of horse spleen ferritin. (a) Complete structure of the 24-meric protein assembly. (b) Outer and inner diameters of the protein cage. ${ }^{14}$ Reproduced with permission from Wiley-VCH Verlag GmbH \& Co, see ref. 14.

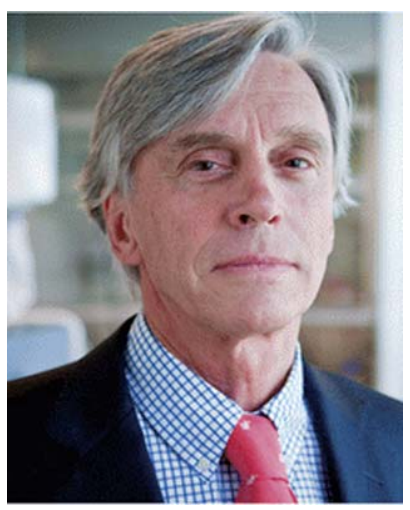

Roeland J.M. Nolte
Roeland J.M. Nolte is Emeritus Professor of Organic Chemistry at the Radboud University Nijmegen, the Netherlands. He is a member of the Royal Netherlands Academy of Science and holds a special Royal Academy of Science Chair in Chemistry. His research interests span a broad range of topics at the interfaces of Supramolecular Chemistry, Macromolecular Chemistry, and Biomimetic Chemistry, in which he focuses on the design of catalysts and (macro)molecular materials.

His contributions to science have been recognized with numerous award lectureships and several national and international prices including the Izatt-Christensen Award for Excellence in Macrocyclic Chemistry, the first Royal Netherlands Academy of Science Chair in Chemistry, and a knighthood in 2003. He has served on the editorial boards of many scientific journals, including the journal Science (Washington) and the RSC journal Chemical Communications (as Chairman).

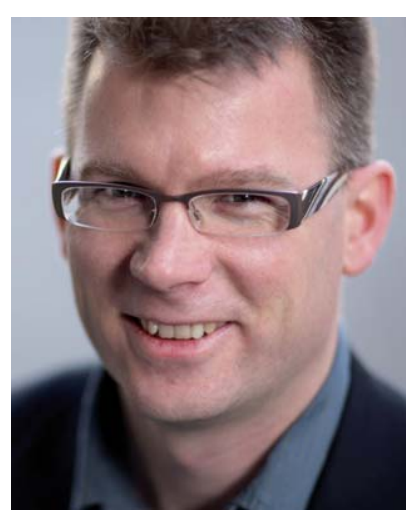

Jeroen J.L.M. Cornelissen
Jeroen J.L.M. Cornelissen is Professor in Biomolecular Nanotechnology at the University of Twente, Enschede, the Netherlands. He studied chemistry at the Radboud University Nijmegen, the Netherlands where he received his $P h D$ (cum laude) in 2001 for research carried out under the supervision of Prof. R.J.M. Nolte. After post-doctoral work at the IBM Almaden Research Center in San Jose, USA he returned to Nijmegen, where he was appointed as an Assistant Professor until 2009. His current research interests are in welldefined polymer architectures, hybrid systems of synthetic macromolecules and biopolymers and the use of viruses as building blocks in functional materials. Jeroen Cornelissen is the recipient of, among other prices, a 2007 EURYI Award and the Golden Medal of the Royal Netherlands Chemical Society in 2011. 
Small channels located at the subunit junctions are required for the release of iron and transport of other metal ions and small organic molecules. ${ }^{21}$ The protein shell of ferritin has several functions: it acquires $\mathrm{Fe}^{\mathrm{II}}$, catalyses its oxidation and induces mineralization within the cavity, which can store up to 4500 iron atoms. This high storage capacity is achieved by sequestering the iron as a compact mineral, which resembles the structure of the mineral ferrihydrite $\mathrm{FeO}(\mathrm{OH})$. To perform these functions, the protein shell contains two structurally similar, but mechanistically different protein subunits, the heavy $(\mathrm{H})$ and light $(\mathrm{L})$ chains. The H-type subunit catalyses the oxidation of $\mathrm{Fe}^{\mathrm{II}}$ to $\mathrm{Fe}^{\mathrm{III}}$, while the L-type subunit promotes mineralization inside the protein cage.

In 1991, Mann and co-workers pioneered the use of ferritin as a nanosized bioreactor. Their main goal was to produce monodisperse metal particles from other metals than iron inside the ferritin cavity. ${ }^{22}$ They applied horse spleen apoferritin (HSFn) to produce iron sulfide particles, as well as manganese oxide and uranyl oxohydroxide crystals. ${ }^{22-24}$ The iron sulfide particles were formed by an in situ reaction of the native iron oxide cores. By reacting the ferritins with $\mathrm{H}_{2} \mathrm{~S}$ or $\mathrm{Na}_{2} \mathrm{~S}$ in an aqueous buffer, the ferrihydrite cores were transformed into iron sulfide nanoparticles. Soon thereafter, they also showed that manganese oxide could be formed by redox-driven reactions in the apoferritin cavity. ${ }^{23}$

Using similar biomineralization strategies, many different inorganic nanoparticles have since then been synthesized inside the core of apoferritin. These include cobalt oxide, cobalt oxohydroxide, chromium hydroxide, nickel hydroxide, indium oxide, cadmium sulfide, cadmium selenide, zinc selenide, magnetite, cobalt/platinum alloys, platinum and other particles. ${ }^{14,25-30}$ Some of the recent publications on inorganic nanomaterial synthesis inside the apoferritin cavity, beyond particle formation, are described in more detail below.

Douglas and co-workers studied the use of the protein constrained iron oxide core of ferritin as a photoreduction catalyst. ${ }^{31}$ In this work, the authors showed that the native ferric oxyhydroxide ferrihydrite $\mathrm{Fe}(\mathrm{O}) \mathrm{OH}$ encapsulated within the protein cage of ferritin could act as a semiconductor photocatalyst for the reduction of the highly toxic $\mathrm{Cr}^{\mathrm{VI}}$ to the more benign $\mathrm{Cr}^{\mathrm{III}}$. With this strategy at hand, the same group used the ferritin system to catalyze the photoreduction of $\mathrm{Cu}^{\mathrm{II}}$ to a colloidal dispersion of $\mathrm{Cu}^{0}$ with a narrow size distribution. ${ }^{32}$ It was also observed that a higher $\mathrm{Cu}^{\mathrm{II}} /$ ferritin ratio led to larger $\mathrm{Cu}^{0}$ particle sizes.

A few years later, the group of Watanabe used a similar approach for the development of a size-selective hydrogenation biocatalyst. ${ }^{14}$ They encapsulated a Pd nanocluster inside the apoferritin cavity by in situ chemical reduction of encased $\mathrm{Pd}^{\mathrm{II}}$

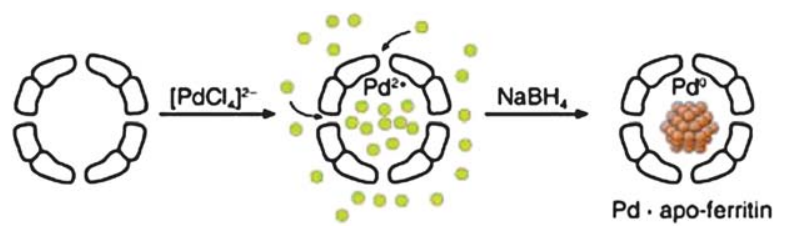

Fig. 2 Schematic representation of the preparation of Pd-apoferritin. ${ }^{14}$ Reproduced with permission from Wiley-VCH Verlag GmbH \& Co, see ref. 14. ions using $\mathrm{NaBH}_{4}$ (Fig. 2). This hybrid metal catalyst was subsequently used for the hydrogenation of a series of olefins. Ferritin contains eight negatively charged pores which are located at the junctions of three subunits. Substrate charge might therefore influence the diffusion of substrate into the cavity. The effect of substrate charge on catalytic hydrogenation efficiency of the $\mathrm{Pd}$-apoferritin hybrid was therefore evaluated. When anionic or bulky substrates were used, only low turnover frequencies were obtained, but when small, cationic substrates were utilized, high turnover frequencies were observed. These results suggest that the system discriminates based on the size and charge of the substrates.

After having successfully incorporated Pd-complexes in the apoferritin cavity, Watanabe and co-workers proceeded with the encapsulation of $\mathrm{Rh}^{\mathrm{II}}$-complexes for the polymerization of phenylacetylene inside the cavity (Fig. 3). ${ }^{33}$ Because of the constrained environment of the ferritin cage, polymers with a narrower weight distribution were obtained than when phenylacetylene was polymerized by the same Rh-catalyst in bulk. The resulting polymers also have a restricted molecular weight $\left(\sim 13 \mathrm{~kg} \mathrm{~mol}^{-1}\right)$, and just a few polymer chains can be prepared within one apoferritin cage. This suggests that the polymerization is limited by the available space in the ferritin cavity.

Kramer et al. synthesized silver nanoparticles within the cavity of ferritin by using a similar encapsulation approach combined with genetical modification of the ferritin interior. ${ }^{35}$ The authors modified the $\mathrm{C}$-terminus of the L-chain of ferritin with a dodecapeptide, AG4, which was previously identified from a phage display library to be able to reduce silver ions to metallic silver. This method yielded spherical particles with an average diameter of $7 \pm 1 \mathrm{~nm}$.

Recently, Kasyutich et al. developed another strategy to synthesize homogeneous silver nanoparticles using ferritin protein cages ${ }^{34}$ It was already suggested in the literature that two parameters are important for obtaining an efficient metal-ion incorporation and a narrow size distribution of the formed nanoparticles inside the protein cage. These are the ratio of external/internal charge distribution ${ }^{36,37}$ and the number of available metal-binding/nucleation sites. ${ }^{38}$ On the basis of the literature data the authors utilized ferritin from the hyperthermophilic archaeon Pyrococcus furiosus ( $\mathrm{PfFt}$ ), a protein with a distinctive charge distribution and fewer iron nucleation sites compared to other ferritins. By using the PfFt-cage, silver nanoparticles of $2.1 \pm 0.4 \mathrm{~nm}$ were obtained (Fig. 4), with a high stability in water and a high thermal stability (up to $\sim 90{ }^{\circ} \mathrm{C}$ ). Other ferritins did not give these results.

Aime et al. entrapped up to $10 \mathrm{Gd}^{\mathrm{III}}$-chelates in the cavity of apoferritin, which resulted in a complex that exhibited high relaxivity of water protons with potential applications in

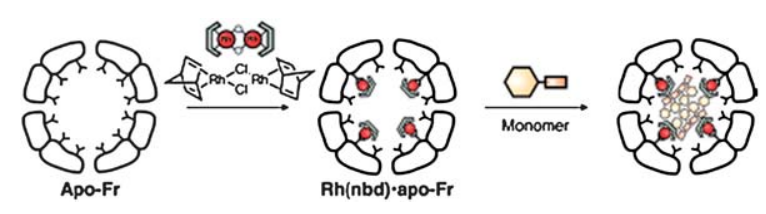

Fig. 3 Schematic representation of a Rh-catalyzed polymerization inside apoferritin. ${ }^{33}$ Reproduced with permission from ACS publications, see ref. 33 . 

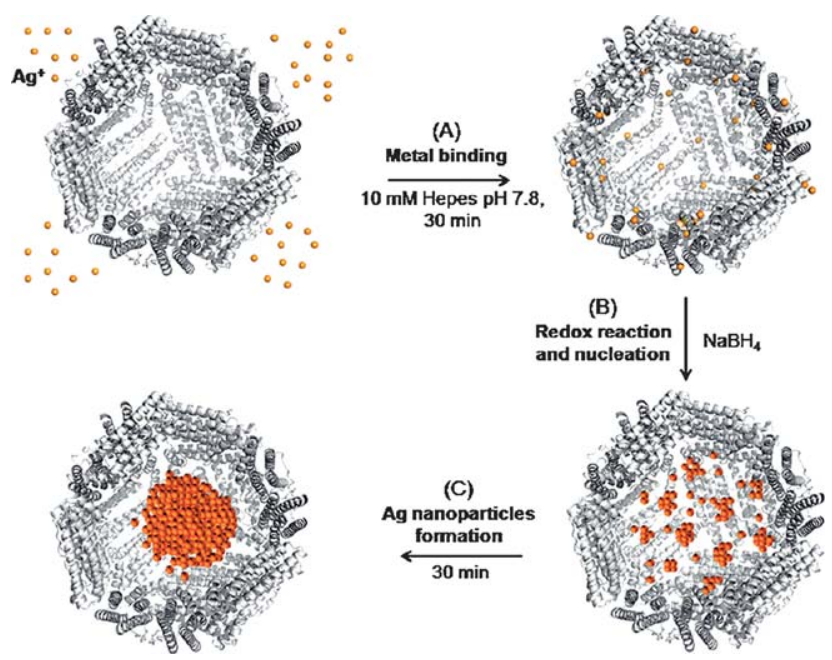

Fig. 4 Silver ions (yellow) access the cavity of Pyrococcus furiosus and bind to the binding/nucleation centers at the internal surface. Ag nanoparticles are shown in orange. ${ }^{34}$ Reproduced with permission from ACS publications, see ref. 34 .

magnetic resonance imaging (MRI). ${ }^{39}$ Though this work is very promising, it does not describe chemical reactions within the cavity of protein cages and is therefore not further discussed here.

The group of Mann also created magnetic nanoparticles by synthesizing ferromagnetic nanocrystals of magnetite $\left(\mathrm{Fe}_{3} \mathrm{O}_{4}\right)^{40,41}$ and magnetite/maghemite $\left(\mathrm{Fe}_{3} \mathrm{O}_{4} / \gamma-\mathrm{Fe}_{2} \mathrm{O}_{3}\right)^{42}$ within the ferritin cavity to yield a magnetic protein, called 'magnetoferritin'. Apoferritin, loaded with various amounts of iron ${ }^{\mathrm{II}}$ ions, was oxidized by trimethylamino- $N$-oxide (Fig. 5). In this method, the authors used the unusual stability of the apoferritin cage at high temperature $\left(60^{\circ} \mathrm{C}\right)$ and $\mathrm{pH}(8.5)$. This approach resulted in the formation of crystalline inorganic particles with diameters of approximately 6-7 nm. A few years later, Klem et al. reported the preparation of metal oxide nanoparticles containing both $\mathrm{Fe}$ and Co oxides. ${ }^{43}$ By controlling the addition of $\mathrm{Co}$ to the reaction mixture, a two- to fourfold increase in the ferromagnetic blocking temperature (with respect to 'Fe-pure' magnetoferritin), was observed.

\section{Dps ferritin}

Dps are a member of the ferritin superfamily. They prevent DNA damage by condensing DNA, and by accumulating iron atoms within their central cavity that might otherwise have produced

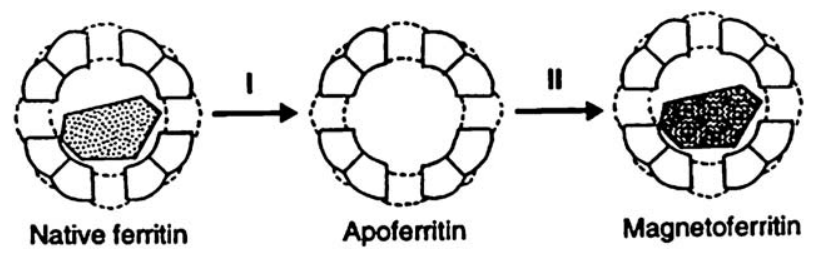

Fig. 5 Schematic representation of the formation of magnetoferritin from native ferritin. First, the native ferrihydrite cores from horse spleen ferritin are removed by dialysis at $\mathrm{pH} 4.5$. Then, apoferritin is reconstituted with a $\mathrm{Fe}^{\mathrm{II}}$-solution under slow oxidative conditions at $60^{\circ} \mathrm{C}$ and pH 8.5. ${ }^{41}$ Reproduced with permission from AAAS, see ref. 41 . free hydroxyl radicals by reaction with hydrogen peroxide. ${ }^{44,45}$ Dps uses the hydrogen peroxide to oxidize iron, resulting in an iron oxide core similar to that of ferritins. ${ }^{46}$ Dps is structurally similar to ferritin. Its 12 Dps subunits have a similar structure as the ferritin subunits and the overall architecture resembles that of the ferritin cage. ${ }^{47,48}$ As ferritin contains twice as much subunits as Dps, the Dps cage is smaller, i.e. it has an outer diameter of $8.5 \mathrm{~nm}$ and an inner diameter of $5 \mathrm{~nm}$. Structural analysis indicates that the $0.8 \mathrm{~nm}$ pores at the subunit interfaces should allow molecular access to the interior cavity of the protein cage ${ }^{49} \mathrm{Dps}$ can accumulate 500 iron atoms within its small cavity. It is suggested from X-ray crystal structural data that six clusters on the interior surface could act as analogues of the mineral nucleation sites in ferritin. ${ }^{49}$

The Dps protein cage was also utilized as a size and shape constrained nanoreactor, as previously described for ferritin. Ferrimagnetic iron oxide, ${ }^{15}$ cobalt oxide, ${ }^{50}$ cadmium sulfide ${ }^{51}$ and platinum nanoparticles ${ }^{52}$ were synthesized within this cage. It is worth mentioning that for the first time, the formation of these particles was monitored by Kang et al. ${ }^{52,53}$ by mass spectrometry.

To enhance the formation of nanoparticles, Swift et al. replaced the 120 surface accessible hydrophilic residues of Dps with hydrophobic amino acids. ${ }^{54}$ Despite these mutations, the Dps proteins were still able to self-assemble and mineralize iron.

\section{Heat shock proteins}

Heat shock proteins are produced in high levels in response to cellular stress, and assist in the correct folding of proteins. The sHsp cage from the hyperthermophilic archaeon Methanococcus jannaschii consists of 24 subunits of $16.5 \mathrm{kDa}$ which self-assemble into a cage with octahedral symmetry. ${ }^{55}$ The major difference between this cage structure and that of the ferritins is the large pores ( $3 \mathrm{~nm}$ in diameter) in the sHsp cage. ${ }^{56}$ The cage is stable in the $\mathrm{pH}$ range 5-11 and can withstand temperatures up to $70{ }^{\circ} \mathrm{C}$. It has an exterior diameter of $12 \mathrm{~nm}$.

Douglas and co-workers functionalized both the interior and exterior surfaces of sHsp with organic and inorganic groups. ${ }^{57} \mathrm{By}$ genetic manipulation of the protein, thiol groups and endogenous amine groups on both the exterior and interior surfaces were used to attach different molecules for the templating sizeconstrained synthesis of inorganic materials. Because of the large pores present in the sHsp cage, the functional groups on the interior can easily react with guest molecules. This property has also been used to achieve the chemical attachment of doxorubicin, a chemotherapeutic agent, in the cavity of sHsp. ${ }^{58}$

Like ferritin, sHsp was also used as a reaction vessel for biomimetic mineralization reactions. ${ }^{57,59}$ Transition metals, iron oxide and alloy nanoparticles were entrapped and synthesized within the sHsp protein cage.

Recently, the group of Douglas reported the synthesis of a cross-linked, branched polymer network inside the protein cage of sHsp. ${ }^{60}$ A genetic sHsp construct with cysteine residues located on its interior surface was used to initiate polymer growth by reaction of the cysteines with a bromo-alkyn. Click-chemistry was then applied to synthesize polymers within this cage, by the sequential coupling of multifunctional monomers. It was observed that the stability of cages increased dramatically upon 
encapsulation of the branched polymer. The cages were able to withstand heat treatment that would otherwise completely disrupt the native protein cage.

Another heat shock protein, Hsp60, which has a cage of $17 \mathrm{~nm}$ in diameter, self-assembles into an octadecameric double ring cage structure, which stacks into patterned arrays. The subunits were genetically modified to display a histidine sequence on the interior of the cage, creating a region with high affinity for metal ions. The modified cage was used to template the synthesis of $\mathrm{Ni}-$ Pd alloy nanoparticles. ${ }^{61}$

\section{Barrel-shaped protein assemblies}

Barrel-shaped protein assemblies, such as molecular chaperonins, have also been used to accommodate inorganic nanoparticles. For example, GroEL is a protein assembly of 14 identical subunits, which stack into rings, yielding a barrel-shape structure of $800 \mathrm{kDa}$ with a diameter of $4.5 \mathrm{~nm} .^{62}$ Its function is to bind denatured proteins and assist in their folding which takes place in its cavity. Aida and co-workers used GroEL for the encapsulation and triggered release of nanoparticles. ${ }^{63}$ However, as far as we know, no examples of synthesis inside the cavity of chaperonins have been reported.

\section{Viruses}

In nature, viruses infect host cells in which they replicate and then exit the cell. During these processes, viruses encounter a broad range of chemical environments. To be able to survive the harsh conditions outside cells but release their cargo when inside, viruses have balanced assembly and disassembly characteristics. All viruses package viral nucleic acid, but many can assemble (naturally or manipulated) into viral capsids, devoid of genetic material, allowing scientists to replace the virus' natural cargo with a non-viral cargo compound. This can be accomplished in two different ways: the cargo can be synthesized in a preassembled capsid, or the protein cage can assemble around an existing cargo. The first method, in which the capsid itself acts as a nanoreactor, is used for the biomineralization of inorganic materials inside the capsid. The latter process is being referred to as encapsidation. ${ }^{65}$

In contrast to the previously discussed protein cages, viruses exhibit a much larger variety in sizes and shapes (Fig. 6). When we look at their morphology, a distinction can be made between icosahedral capsids (quasi-spherical structures) and helical capsids (rod-shaped structures). Icosahedral capsids range in size from 18 to $500 \mathrm{~nm}$ in diameter, but filamentous or rod-shaped viruses like TMV can form rods up to $2 \mu \mathrm{m}$ in length. ${ }^{65}$

Virus particles generally consist of several hundred protein molecules which can self-assemble to form highly symmetrical structures that contain the viral nucleic acid. The subunits from which the viral capsid is built up can be manipulated both genetically and chemically, often without changing the overall architecture of the virus particles that they form. Like protein cages, the interior of viruses can often be modified via the pores in the capsid. Some viruses can self-assemble in the absence of the endogenous nucleic acids. ${ }^{13}$
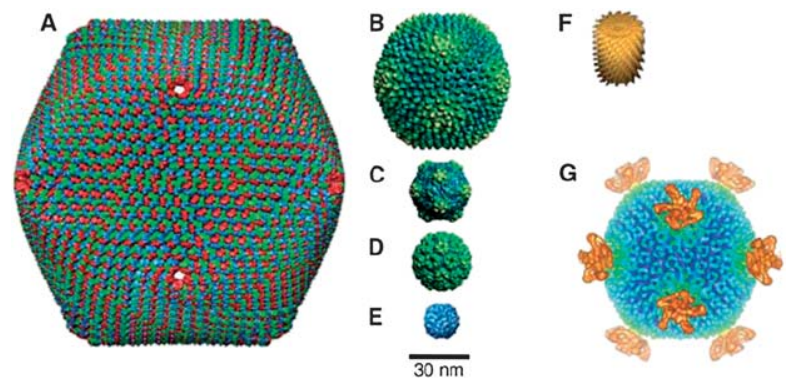

Fig. 6 Cryo-electron micrograph and image reconstructions of a variety of viral capsids. ${ }^{64}$ (A) Paramecium bursaria Chlorella virus type I (PCB1), $170 \mathrm{~nm}$ diameter. (B) Murine polyomavirus (MPV), $51 \mathrm{~nm}$ diameter. (C) Cowpea mosaic virus (CMV), $31 \mathrm{~nm}$ diameter. (D) Cowpea chlorotic mottle virus (CCMV), $28 \mathrm{~nm}$ diameter. (E) Satellite tobacco mosaic virus (STMV), $18 \mathrm{~nm}$ diameter. (F) Small section of rod-shaped TMV, 18 by $300 \mathrm{~nm}$. (G) Sulfolobus turreted icosahedral virus (STIV) isolated from Yellowstone National Park. Reproduced with permission from AAAS, see ref. 64 .

The variety in shape and size, and the self-assembly characteristics make viruses very suitable for the controlled synthesis of inorganic materials or the encapsulation of other materials.

When we regard viral capsids as molecular containers, three surfaces can be exploited: the interior, the exterior, and the interface between the protein subunits (Fig. 7). ${ }^{66}$ In this overview, we will focus on the modification of the inside of viral capsids.

\section{Biomineralization in viruses}

Self-assembled protein cage structures, such as ferritin, have been used for the constrained mineralization of inorganic nanoparticles (see above). ${ }^{15,17}$ However, protein cages are limited to a very small range of sizes and the corresponding shapes. On the

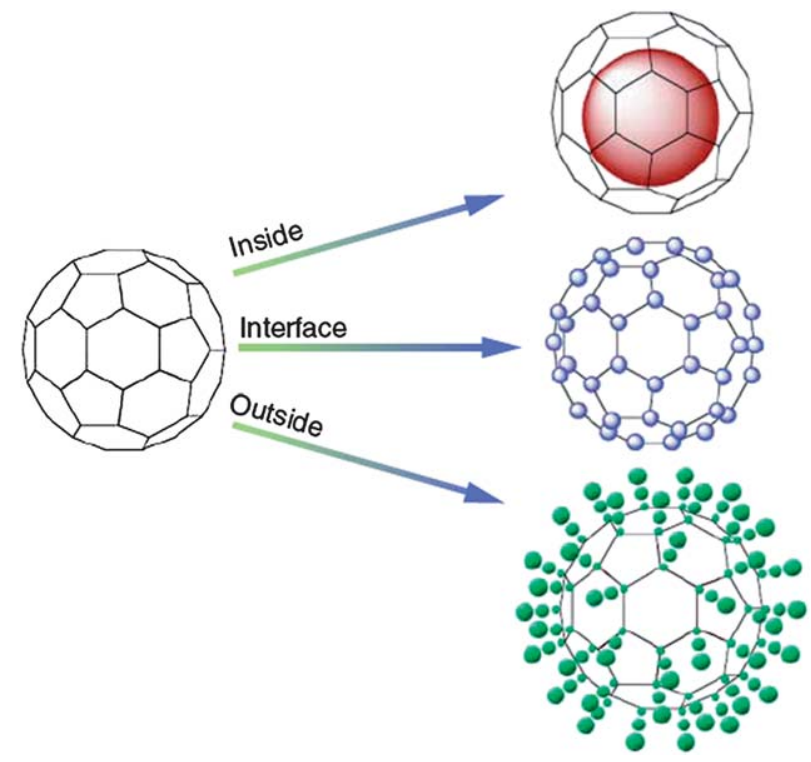

Fig. 7 Schematic representation of the three important interfaces available for chemical and genetic manipulation in a virus particle. ${ }^{64}$ Herein, we will focus on manipulations of the interior cavity of viral capsids. Reproduced with permission from AAAS, see ref. 64 . 
contrary, viruses exist in a wide range of sizes, and, e.g., the CCMV is even known to occur in many different architectural shapes. ${ }^{67}$

Also, because of their specific assembly and disassembly characteristics, viral capsids allow scientists to change their interior. ${ }^{13}$ Therefore, the protein cages of viruses are very suitable for constrained synthesis of inorganic materials.

Douglas and Young were the first to perform inorganic mineralization reactions inside the CCMV capsid. It was already known ${ }^{68}$ that at a $\mathrm{pH}$ higher than 6.5 the capsid has 60 pores with a diameter of $2 \mathrm{~nm}$ and this process is reversed when the $\mathrm{pH}$ is lowered to 5.0. This property of CCMV was used for the oligomerization of tungstate $\left(\mathrm{WO}_{2}{ }^{4-}\right)$ and vanadate $\mathrm{V}_{10} \mathrm{O}_{28}{ }^{6-}$ inside the capsid, which occurs when the $\mathrm{pH}$ is lowered. This approach yielded particles with an average diameter of $15 \mathrm{~nm}^{69}$

A few years later, Douglas and Young showed that the charge on the protein cage interior of CCMV can be altered from cationic to anionic. ${ }^{13}$ This was carried out by replacing nine basic residues at the $\mathrm{N}$-terminus of the CCMV coat protein by glutamic acid residues, but the assembly properties and stability of the formed particle remained similar to the wild-type capsids. The particles that are formed in this manner have a negatively charged interior, which favors interactions with positively charged ferrous and ferric ions. This makes the viral cage suitable for the hydrolysis of $\mathrm{Fe}^{\mathrm{II}}$ to iron oxide, which leads to the size and shape constrained formation of nearly monodisperse iron oxide particles, with an average diameter of $24 \mathrm{~nm} .{ }^{13}$

In a similar approach, the group of Douglas was able to use the CCMV capsid for the biomineralization of $\mathrm{TiO}_{2}$ nanoparticles. ${ }^{70}$ In this study, the authors made use of the wild-type capsid to attract negatively charged $\mathrm{Ti}^{\mathrm{IV}}$ salts, which were subsequently converted to monodisperse $\mathrm{TiO}_{2}$ nanoparticles by changing the $\mathrm{pH}$ of the solution.

De la Escosura et al. were able to synthesize Prussian blue nanoparticles with an average diameter of $18 \pm 1.7 \mathrm{~nm}$, within the cavity of CCMV. ${ }^{71}$ Prussian blue nanoparticles were formed by a photo-initiated reaction. Negatively charged $\left[\mathrm{Fe}\left(\mathrm{C}_{2} \mathrm{O}_{4}\right)_{3}\right]^{3-}$ was accumulated in the capsid interior and produced $\mathrm{Fe}^{\mathrm{II}}$ ions after photoreduction, which further reacted with encapsulated $\left[\mathrm{FeCN}_{6}\right]^{3-}$ to form the Prussian blue clusters (Fig. 8). This is one of the first examples of the synthesis of potentially magnetic nanoparticles inside viral capsids.

Another viral capsid that is being used for the constrained synthesis of magnetic nanoparticles is bacteriophage $T 7 .{ }^{72}$ The interior of this virus can be very easily modified because the capsid is formed first, after which the nucleic acids are condensed within it. The empty capsid is therefore also stable without DNA. The T7 phage has an outer diameter of $55 \mathrm{~nm}$, and the interior diameter is around $40 \mathrm{~nm}$. The growth of cobalt particles inside the $\mathrm{T} 7$ phage was achieved by incubating the empty capsids with a $\mathrm{Co}^{\mathrm{II}}$ solution, after which the mixture was reduced by sodium
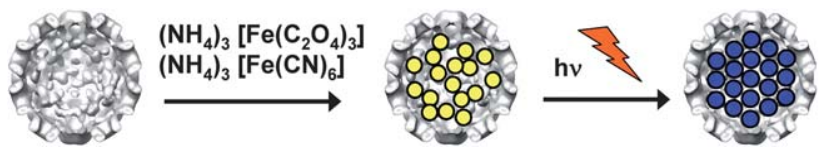

Fig. 8 Schematic representation of the synthesis of Prussian blue nanoparticles within the cavity of CCMV. ${ }^{71}$ borohydride to yield cobalt nanoparticles. By using this approach, uniform cobalt particles of $42 \pm 2 \mathrm{~nm}$ were obtained.

Bacteriophage MS2 is an icosahedral capsid consisting of 180 identical subunits, which self-assemble to form particles with a diameter of $27 \mathrm{~nm}$. An important characteristic of this viral capsid is that it has 32 pores of about $1.8 \mathrm{~nm}$, which enable the diffusion of small molecules into and out of the capsid interior. The group of Francis altered the interior of the MS2 capsid by functionalizing the tyrosine residues using diazo-transfer and hetero-Diels-Alder reactions. ${ }^{73}$ This modification was used to confine $\mathrm{Gd}^{3+}$ binding ligands in the capsids, which could be used for MRI contrast imaging. ${ }^{74}$ Such chemical alterations of the interior of the capsid may also facilitate chemical or enzymatic reactions in the confined space of the nanoreactor, however, such reactions have not been carried out yet.

TMV is a helical, rod-shaped virus of which the interior has been used for the synthesis of nanowires, due to its anisotropic shape and stability. TMV is stable in a wide range of conditions; it can withstand $\mathrm{pH}$ ranges from 3.5 to 9.0 , temperatures up to $90{ }^{\circ} \mathrm{C}$ and organic solvents. ${ }^{66}$ The TMV capsid is made up of 2130 identical subunits, which are recruited by the RNA and assemble around it into a $300 \times 18 \mathrm{~nm}$ helical structure, with a core of $4 \mathrm{~nm}$ in diameter (Fig. 9). The structure of TMV can be seen as a series of rings (comprising 14 subunits) stacked on top of each other. This results in an overall chiral structure and inherent asymmetry which does not exist for icosahedral viruses. This property allows for chemical and physical differentiation on one end of the helical rod. TMV can easily be assembled in vitro and the TMV aspect ratio is determined by $\mathrm{pH}$, ionic strength and protein concentration. ${ }^{18} \mathrm{TMV}$ can also be produced in very high quantities (kilogram scale) from the infected plant material and because of its high stability, it can serve as a template in a wide range of conditions.

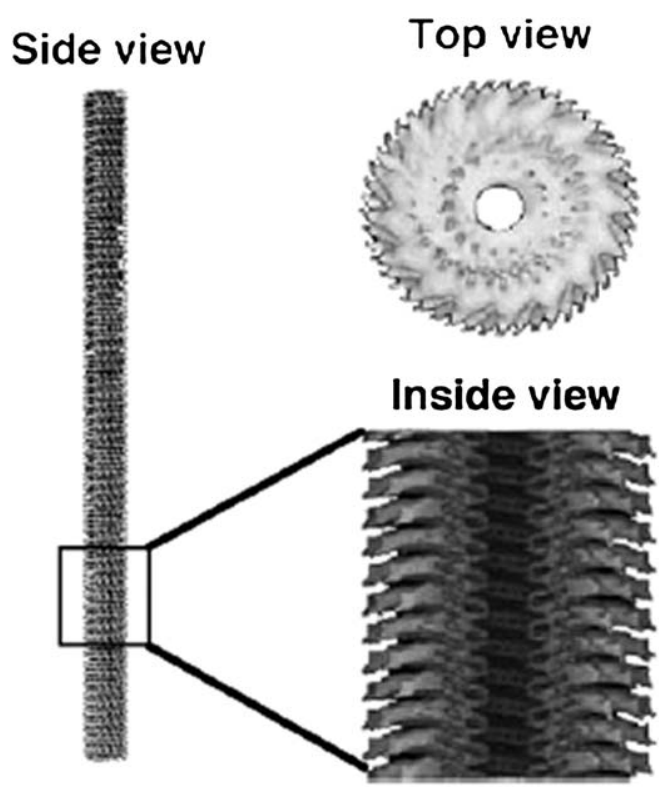

Fig. 9 Cryo-electron imaging reconstructions of tobacco mosaic virus (TMV). The virus is $300 \mathrm{~nm}$ in length, has a diameter of $18 \mathrm{~nm}$ and a $4 \mathrm{~nm}$ channel. ${ }^{18}$ Reproduced with permission from Wiley-VCH Verlag $\mathrm{GmbH}$ \& Co, see ref. 18 . 
The channel of TMV was first used for the synthesis of $\mathrm{Ni}$ and Co nanowires with lengths up to micrometre range, ${ }^{75,76}$ suggesting end-to-end assembly of individual capsids. Later, the narrow channel was used to grow copper nanowires of $150 \mathrm{~nm}$ in length and $3 \mathrm{~nm}$ diameter ${ }^{77}$ and bimetallic alloys of $\mathrm{CoPt}, \mathrm{CoPt}_{3}$ and $\mathrm{FePt}_{3}$ up to $100 \mathrm{~nm}$ length and $4 \mathrm{~nm}$ diameter. ${ }^{78}$

Furthermore, formation of small silver nanoparticles by photochemical reduction of $\mathrm{Ag}^{\mathrm{I}}$ salts at $\mathrm{pH} 7$ within the channel of TMV has also been reported. ${ }^{80}$ In the same publication the authors describe the use of the exterior surface of TMV for the controlled formation of gold and platinum nanoparticles. The group of Francis reported a method for site-selective modification of both the interior and exterior surfaces of TMV to expand the range of applications for which the capsid can be used. $^{81}$

The exterior surface of TMV has been widely used as a template for the synthesis of nanoparticles and nanotubes. ${ }^{76,80}$ These nanotubes are grown from deposited clusters of palladium, platinum, and gold on the exterior TMV surface.

The M13 bacteriophage is another helical virus, which has been extensively studied and has proven to be a valuable tool for the development of functional nano-materials. The M13 bacteriophage does not have an inner cavity in which reactions can be performed, but although this literature overview focuses on reactions on the interior of protein cages, successful studies towards applications validate the discussion of these materials.

The M13 bacteriophage consists of 2700 copies of the $\mathrm{p} 8$ coat protein that assemble around circular single stranded DNA, and minor coat proteins which cap the ends of the structure. The coat proteins can be genetically modified to display peptides with metal-binding sequences. By modification of the minor coat proteins situated at the virus ends with $\mathrm{ZnS}$ binding sequences, and incubation with a $\mathrm{ZnS}$ liquid crystalline suspension, the viruses form highly ordered composite materials. ${ }^{82} \mathrm{~A}$ similar strategy was used to position the virus on single-walled carbon nanotubes (SWNTs). Besides modification of the minor coat proteins with SWNT binding peptides, the major coat proteins of this virus were modified with peptides capable of nucleating amorphous iron phosphate $\left(\mathrm{a}-\mathrm{FePO}_{4}\right)$. A cross-linked network of a-FePO $\mathrm{P}_{4}$ coated viruses attached to SWNTs was thus created (Fig. 10). This network is highly conductive, and was used as the positive electrode of a lithium-ion battery. ${ }^{79}$ This battery is very light-weight and can be produced and disposed of in an environmental friendly manner, in contrast to conventional Li-ion batteries.

\section{Enzymatic reactions inside viral capsids}

In the past few years, there has been a growing interest in mimicking cellular compartments. As mentioned in the Introduction, viruses could serve as useful model systems for the study of enzymatic reactions in confined spaces, due to their monodispersity and small internal volume. In addition, many viruses contain pores through which substrates can enter the capsid. In order to construct a viral nanoreactor, their assembly and disassembly properties could be of use, as well as the accessibility of the capsid to genetic and chemical modification. Despite these promising applications, however, only very few of these viral nanoreactors have been produced thus far. , $^{\mathbf{1 2 , 8 3 , 8 4}}$
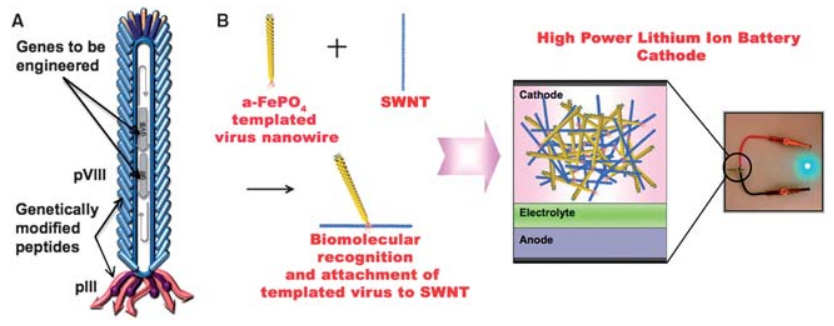

Fig. 10 Schematic representation of the formation of a virus based battery. (A) The minor coat proteins of the M13 bacteriophage are modified with SWNT binding peptides, and the major coat proteins are modified with peptides capable of nucleating a-FePO 4 . (B) Addition of the a-FePO $\mathrm{P}_{4}$ templated virus nanowires to SWNTs results in a highly conductive network, which is used as the positive electrode of a lithiumion battery. ${ }^{79}$ Reproduced with permission from AAAS, see ref. 79 .

A virus that is particularly suitable for the construction of a viral nanoreactor is CCMV. Under influence of the $\mathrm{pH}$ the CCMV capsid devoid of nucleic acids can disassemble into dimers, and reassemble again. This property can be used to entrap enzymes within the capsid, by mixing the enzymes with the disassembled capsid proteins at $\mathrm{pH} 7.5$, and subsequently lowering the $\mathrm{pH}$ to 5.0 to induce capsid assembly (Fig. 11).

Comellas-Aragones et al. used this approach to incorporate horseradish peroxidase (HRP) enzymes in the inner cavity of CCMV ${ }^{8}$ The goal of this project was to study the activity of one single-enzyme present in the capsid. Therefore, the concentration of the enzyme in buffer was lowered to make sure that only one enzyme or no enzyme was encapsulated in the capsid. The enzymatic activity of the encapsulated HRP was examined by confocal fluorescence microscopy. The non-fluorescent dihydrorhodamine $6 \mathrm{G}$ was used as a substrate. Under the influence of HRP this substrate is oxidized to rhodamine $6 \mathrm{G}$ which is highly fluorescent and thus can easily be monitored. The experiment showed that the capsid acts as a nanoreactor and is permeable for both the substrate and product (Fig. 12).

A few years later, Minten et al. ${ }^{84}$ developed a method to encapsulate multiple proteins in the CCMV capsid. The strategy previously described by Comellas-Aragones et al. ${ }^{8}$ could not be applied in this study, because the encapsulation efficiency in this method was too low to encapsulate multiple enzymes. Therefore, the authors designed an approach that utilized non-covalent anchoring of the target protein to the capsid protein dimers, which upon addition of non-functionalized capsid protein could be assembled into capsids containing proteins. As non-covalent

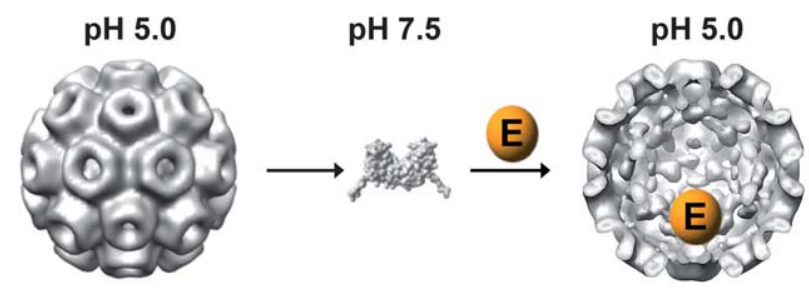

Fig. 11 Schematic representation of enzyme encapsulation in the CCMV capsid. After disassembling into dimers at $\mathrm{pH} 7.5$, the guest enzyme is added and upon decreasing the $\mathrm{pH}$ to 5.0 the capsid assembles with the enzyme entrapped in its cavity. ${ }^{8}$ 


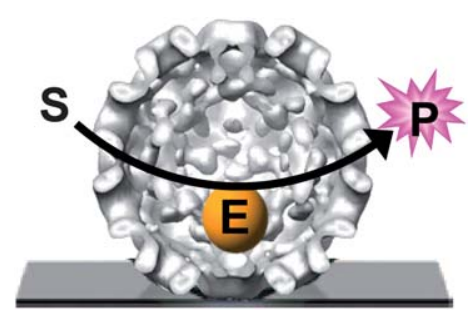

Fig. 12 Single-enzyme study on HRP (E) encapsulated within CCMV. The substrate (S) diffuses into the capsid and is converted into a fluorescent product $(\mathrm{P})$ which accumulates before it diffuses out of the capsid. ${ }^{8}$

anchor, a small heterodimeric coiled-coil protein was used. The capsid protein was modified with the positively charged coiledcoil, while EGFP as a model-system was modified with the negatively charged coiled-coil. When these two complexes were mixed together, the EGFP-capsid protein complex was formed (Fig. 13). After addition of wild-type capsid protein to the complex, capsid formation was induced by lowering of the $\mathrm{pH}$. By varying the ratio between the wild-type capsid protein, and the capsid-EGFP protein complex, the amount of encapsulated proteins could be controlled, and up to 15 EGFP molecules could thus be encapsulated.

Following up on this work, Minten et al. ${ }^{12}$ used this strategy to encapsulate multiple functional enzymes, Pseudozyma (formerly antarctica) lipase B (PalB) in the capsid. Comparison of the catalytic activity of the capsids containing different amounts of encapsulated PalB with non-encapsulated PalB, revealed that the encapsulated PalB converted the substrate more efficiently (Fig. 13). Furthermore, increasing amounts of PalB in the capsid seemed to have a negative effect on the conversion rates. This can be explained by considering that the local concentration of enzyme inside the capsid is higher than the concentration of substrate. Therefore, the conversion rate of substrate molecules does not change when more enzymes are present in the capsid, and thus the overall conversion rate per enzyme decreases.

A $\quad \mathrm{pH} 7.5$

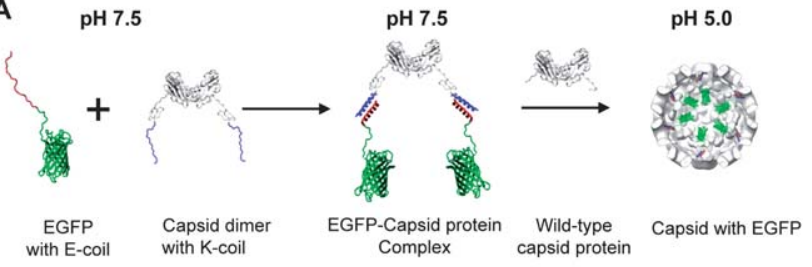

B

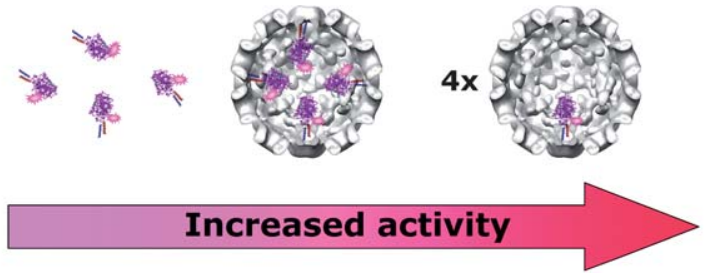

Fig. 13 (A) In this schematic representation it is shown how the EGFPcapsid protein complex together with the wild-type capsid protein assemble into a capsid with EGFP in its interior cavity. ${ }^{84}$ (B) The effect of encapsulation on the activity of PalB enzymes. ${ }^{12}$
These examples clearly show the potential of virus capsids as a nanoreactor, and in the future these capsids might be used for multiple applications, such as performing cascade reactions in the confined space of a virus-based reactor.

Not only plant viruses, but also animal viruses, like the polyomavirus family have been engineered in order to obtain nanocapsules. Simian virus 40 (SV40) and murine polyomavirus (MPV) have been studied extensively for their potential use in delivering biologically active materials. ${ }^{85}$ These are icosahedral, non-enveloped DNA viruses, with an outer diameter of about $45 \mathrm{~nm}$. Their capsid consists of 72 pentamers of the major coat protein VP1 (Fig. 14) ${ }^{86,87}$ The minor coat proteins VP2 and VP3 are associated with the VP1 proteins and are located on the capsid interior. Recombinant VP1 pentamers can self-assemble into genome-free icosahedral virus-like particles (VLPs) both in vitro and in vivo. ${ }^{88-90}$

Recently, many VLPs have been exploited as delivery vehicles. ${ }^{85}$ For polyomaviruses this has been achieved by genetically fusing heterologous proteins to VP1 proteins. ${ }^{91,92}$ However, the particles formed in these studies were irregular and had showed poor solubility when expressed in E. coli.

Inoue $e t$ al. reported a novel strategy for the encapsulation of proteins and enzymes into SV40 VLPs. ${ }^{83}$ In this work, EGFP was fused to the C-terminus of the VP2 and VP3 minor coat proteins, using a flexible linker. When these constructs were co-expressed with VP1, VLPs with EGFP inside were obtained. The resulting capsids retained their ability to bind to, and enter cells, after which the EGFP was delivered. Next, yeast cytosine deaminase (yCD) was encapsulated via the same method. This enzyme converts cytosine to uracil and is used as a prodrug-converting enzyme in gene therapy. It was demonstrated that upon encapsulation the yCD enzymes retained most of their activity.

To the best of our knowledge, no enzymatic reactions inside other capsids have been described so far.

Helical viruses have not been used for the encapsulation of enzymes because their internal channel is too narrow for these purposes. ${ }^{1}$ However, Candida antarctica lipase B (CalB), more recently renamed Pseudozyma antarctica lipase B (PalB), has been linked to the surface of potato virus $\mathrm{X}(\mathrm{PVX}){ }^{93}$ This virus

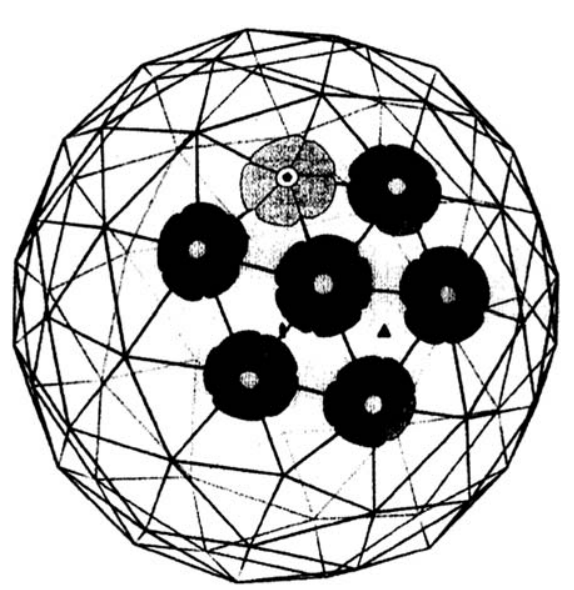

Fig. 14 Architecture of the SV40 capsid. Arrangement of the pentamers on the $T=7$ icosahedral lattice. ${ }^{87}$ Reproduced with permission from Elsevier Ltd, see ref. 87. 
particle has a flexible rod-shaped structure, which is $500 \mathrm{~nm}$ in length and has a diameter of $13 \mathrm{~nm}$. It is build up from 1270 identical coat proteins. The authors linked the lipase to the Nterminus of the coat protein by constructing a PalB-coat protein fusion protein. In this way the PalB was positioned at the exterior of the virus particle (Fig. 15). The lipase remained catalytically active, and this work suggests that in the future multiple types of enzymes can be linked to the exterior of a viral capsid, in order to catalyze multi-step enzymatic synthesis. These types of reactions are not constrained by the dimensions of the virus, and will therefore not be discussed further in this overview.

\section{Molecular microcompartments and bacterial enzymes}

A family of bacterial proteins that resemble virus capsids are the encapsulins (in the literature also referred to as linocin-like proteins), which form assemblies with a diameter of about $20 \mathrm{~nm}$ and have icosahedral symmetry. Although the sequence similarity between encapsulins and viral proteins is weak, the proteins show great structural similarity to virus capsid proteins. These nanocompartments package enzymes, and are thus excellent examples of nanoreactors. The group of Ban studied this protein family ${ }^{94}$ and found two different proteins that can be packaged within the encapsulins; i.e. a peroxidase or a protein that has the same fold as ferritin monomers and contains the ferroxidase active site. Interestingly, the pores of encapsulin resemble those of ferritin. The proteins are attached to the encapsulin shell using a C-terminal extension that interacts with a binding site of the encapsulin proteins.

Besides nanocompartments, many bacterial species produce microcompartments to confine enzymes that have toxic or volatile intermediates, or to increase the local enzyme concentration. These microcompartments are solely composed of proteins. The carboxysome for example is a bacterial microcompartment that packages the enzyme ribulose bis-phosphate carboxylase oxygenase ( $\mathrm{RuBisCO}$ ) by forming polyhedral bodies with a diameter of $80-140 \mathrm{~nm} \cdot{ }^{95-97}$ Other examples are the Eut and Pdu organelles, which also are likely to package enzymes from metabolic pathways. ${ }^{98,99}$ A eukaryotic microcompartment built of protein subunits is the vault particle. ${ }^{100}$

In contrast to protein microcompartments, where structural proteins form the walls of the compartment, multi-enzyme complexes exist, in which the enzymes themselves form the walls of the complex. Substrates can enter these complexes but they are not permeable to other macromolecules. Examples are lumazine synthase, ${ }^{101}$ fungal fatty acid synthase ${ }^{102}$ and the pyruvate dehydrogenase complex. ${ }^{103}$

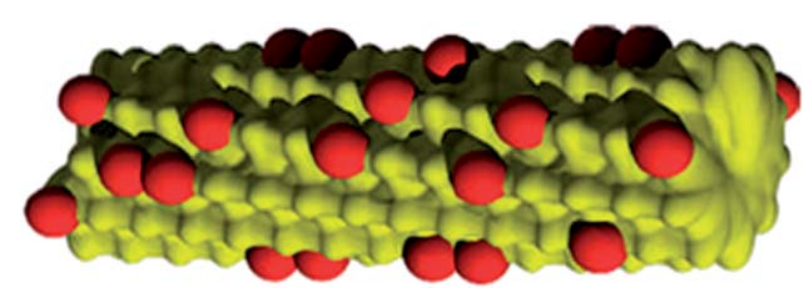

Fig. 15 Schematic representation of the PVX virus particle (yellow) with the PalB enzyme molecules (red) on its surface. ${ }^{93}$ Reproduced with permission from Nature publishing group, see ref. 93.

\section{Bacterial microcompartments}

For diverse bacteria it is known that they produce proteinaceous intracellular compartments to entrap enzymes, to confine them and as such increase their local concentration. ${ }^{94}$ However, the mechanisms by which bacterial microcompartments like ethanolamine utilization (Eut) and propanediol utilization (Pdu) encapsulate their enzymes are not very well understood.

The best studied bacterial microcompartment is the carboxysome, which confines $\mathrm{CO}_{2}$ in the vicinity of $\mathrm{RuBisCO}$ to enhance autotrophic $\mathrm{CO}_{2}$ fixation. ${ }^{11}$ Although this microcompartment can be viewed as a potential nanoreactor for enzymatic reactions, since in nature its function is already to encapsulate enzymes, no such applications of the carboxysome have been published yet.

Another bacterial microcompartment that gains interest is the Pdu which is used for the $\mathrm{B}_{12}$-dependent degradation of 1,2propanediol (1,2-PD). The first two steps of 1,2-PD degradation occur in the lumen of Pdu, the last two in the cytoplasm of the cell. ${ }^{11}$ Pdu consists of 14 different polypeptides, including seven different shell proteins and four enzymes. ${ }^{104}$ The encapsulated enzymes include CoA-dependent propionaldehyde dehydrogenase $(\mathrm{PduP})$, which converts 1,2-PD to propionyl-CoA via a propionaldehyde intermediate. The function of $\mathrm{Pdu}$ is to sequester propionaldehyde to protect cells from DNA damage and cytotoxicity.

Fan et al. showed that short N-terminal peptides of Pdu and other proteinaceous microcompartments (MCPs) play a major role in the encapsulation of enzymes. ${ }^{11}$ In the same publication, the authors show that fusion of the 18-amino acid N-terminal sequence of PduP to green fluorescent protein (GFP), glutathione S-transferase (GST) or a maltose-binding protein (MBP) resulted in their encapsulation in Pdu. Though the exact binding mechanism of the N-terminal sequences to the microcompartments is not known, from these experiments it is clear that they play an essential role for the binding of certain enzymes to the interior of the microcompartments.

Since recombinant enzymes containing these N-terminal extensions are readily made, this discovery offers great potential for the utilization of microcompartments as nanoreactors. As these compartmental structures have only recently been discovered and studied, this has not been accomplished yet, at least to the best of our knowledge.

\section{Vault nanoparticle}

Vaults are large ribonucleoprotein capsules with dimensions of $42 \times 42 \times 75 \mathrm{~nm},{ }^{105}$ a thin protein shell of $2 \mathrm{~nm}$ thick, surrounding an inner cavity large enough to encapsulate hundreds of proteins (Fig. 16). ${ }^{9}$ Vaults consist of four components: 96 copies of the major vault protein (MVP), vault poly(ADP ribose) polymerase (VPARP), telomerase-associated protein 1 (TEP1), and untranslated vault RNA. Recombinant MVPs expressed in insect cells can self-assemble into a vault-like particle, without the remaining components.

The group of Rome has studied the properties of the vault capsules, mainly for their potential as a drug delivery vehicle. ${ }^{106,107}$ Because vaults are abundant in most eukaryotes, including humans, they are less expected to elicit an 


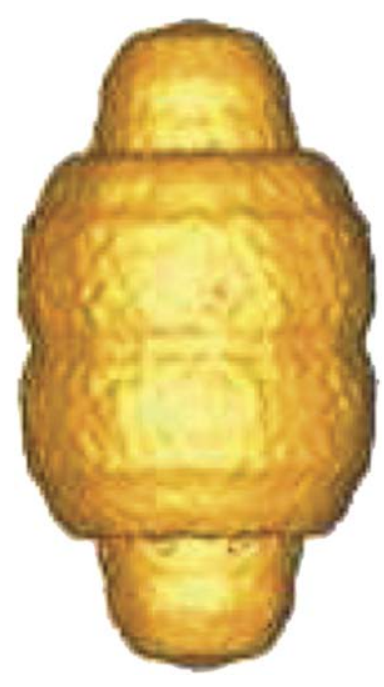

Fig. 16 Vault reconstruction with imposed eight-fold symmetry.9 Reproduced with permission from Elsevier Ltd, see ref. 9.

immunogenic response than virus capsids or bacterial microcompartments.

First, the authors demonstrated that luciferase could be encapsulated in the cavity of the vault, by fusing the luciferase encoding DNA to the vault interaction domain and inserting it into the baculovirus expression vector. ${ }^{108}$ In a similar way, a variant of GFP (green lantern) was also sequestered within the vault cavity. Luciferase was still active after encapsulation but its activity seemed to be affected by a diffusion barrier for charged molecules.

A few years later the same group showed that a semiconductor polymer could be encapsulated in recombinant vaults. ${ }^{109}$ This study provided important insight into the encapsulation process of nonbiological cargos which could be applied in the sequestration of drug molecules. Recently, gold nanoclusters and histidine-tagged proteins have been targeted to the inner wall of vault particles by using a carrier derived from a vault lumenassociated protein. ${ }^{106}$

\section{Lumazine synthase}

Lumazine synthase is a hollow 1 MDa bacterial enzyme complex, consisting of 60 subunits. It is involved in the synthesis of lumazine, which is a precursor to riboflavin. X-Ray structure analysis showed that lumazine synthase is a hollow sphere with $T=1$ icosahedral symmetry, with an outer and inner diameters of $14.7 \mathrm{~nm}$ and $7.8 \mathrm{~nm}$ respectively. ${ }^{110}$ The inner wall of the capsid is negatively charged, due to the presence of glutamic acid residues. The interior of the lumazine synthase capsid can be accessed via hydrophilic channels, which are lined with the glutamic acid residues and located at the ten threefold axes. ${ }^{101}$ Channels consisting of symmetrically arranged $\alpha$-helices are present along the six five-fold pentamer $\operatorname{axes}^{110}$ (Fig. 17). The pores formed by these channels at the interior surfaces are surrounded by polar residues and probably play an important role in substrate import and product export from the enzyme catalytic sites located at the interior of the complex. ${ }^{111}$ The capsid is highly stable at $\mathrm{pH} 7$ in the presence of phosphate buffer or substrate analogues. In the absence of ligands, the structure can dynamically be rearranged to form larger particles, with an external diameter of $30 \mathrm{~nm} .^{112}$

Shenton et al. investigated the potential of the lumazine synthase capsid as a bio-nanoreactor for the mineralization of iron oxide. ${ }^{113}$ In the environment which the authors used for this reaction ( $\mathrm{pH} 6.5$ and absence of ligands) the capsids had an internal diameter of $20 \mathrm{~nm}$ and an external diameter of $30 \mathrm{~nm}$, as confirmed by transmission electron microscopy (TEM). Mineralization of iron oxide was induced by adding aliquots of $\mathrm{Fe}^{\mathrm{II}}$ to the buffer solution. The formation of electron dense iron-containing nanoparticles was confirmed by TEM images and corresponding energy dispersive X-ray analysis (EDX). The ratio of $\mathrm{Fe}^{\mathrm{II}}$ ions/subunits lumazine synthase was varied in the experiments. More $\mathrm{Fe}^{\mathrm{II}}$ ions per subunit resulted in more electron dense and more crystalline iron-containing nanoparticles. The diameter of these particles varied between 10 and $15 \mathrm{~nm}$. TEM measurements on the iron-containing capsids revealed that the formed capsids were mostly $30 \mathrm{~nm}$ in diameter, but that a small percentage was in the native form of $15 \mathrm{~nm}$ in diameter. This suggests that the native form is destabilized by the presence of $\mathrm{Fe}^{\mathrm{III}}$ ions and transforms into a higher ordered structure. The authors thus showed that it is possible to use a hollow bacterial enzyme complex for the mineralization of inorganic nanoparticles. They also suggested that due to the presence of both positively and negatively charged channels in the capsid, it should be possible to sequester cationic and anionic reactions for the synthesis of other nanoparticles (as previously demonstrated for ferritin).

A few years later, Seebeck et al. reported an encapsulation method for lumazine synthase which utilizes a tagging system based on charge complementarity. ${ }^{10}$ The authors used lumazine synthase from Aquifex aeolicus which they genetically engineered in such a way that four residues per monomer, which project into the lumen, were mutated to glutamic acid residues, to create an additional negative charge on the interior surface of the capsid (Fig. 18). As the capsids contain either 60 or 180 subunits, these mutations, therefore, could yield 240 or 720 extra negative charges, respectively. Furthermore, a histidine-tag was incorporated at the $\mathrm{C}$-terminus of the protein to facilitate purification. The negatively charged lumazine synthase was brought to expression in E. coli and this yielded capsids which can withstand temperatures up to $95{ }^{\circ} \mathrm{C}$. Next, the authors showed that

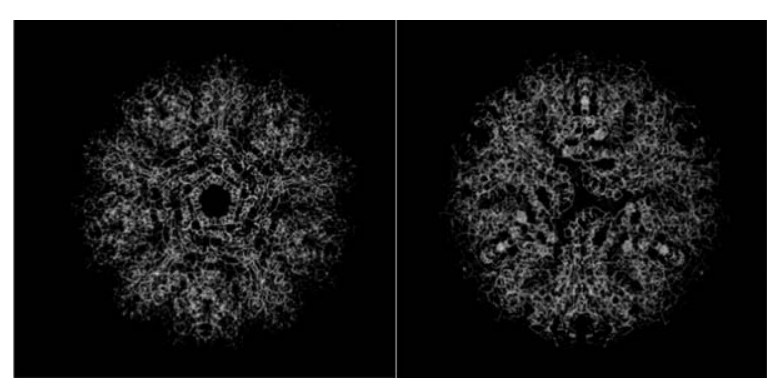

Fig. 17 Models of the 60-subunit lumazine synthase capsid. Left: view from the 5-fold icosahedral axis; one of the 12 channels is clearly visible. Right: view from the 3-fold icosahedral axis. ${ }^{110}$ Reproduced with permission from Elsevier Ltd, see ref. 110. 

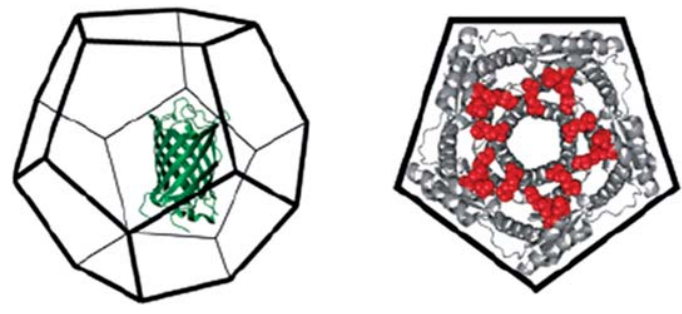

Fig. 18 Left: sequestration of GFP in the lumazine synthase capsid, based on the crystal structure of the $T=1$ capsid formed by $A$. aeolicus. Right: lumazine synthase pentamer. In red are the four mutated glutamic acid residues. ${ }^{10}$ Reproduced with permission from ACS publications, see ref. 10 .

a positively charged stretch of amino acids added to a cargo protein led to encapsulation of the cargo protein. This was carried out by fusing a deca-arginine $\left(\mathrm{R}_{10}\right)$ tag to the $\mathrm{C}$-terminus of GFP. When co-produced with the lumazine synthetase, GFP$\mathrm{R}_{10}$ was encapsulated in the negatively charged lumazine synthase capsid. Sedimentation equilibrium data and scanning force microscopy (SFM) revealed that both $T=1$ capsids consisting of 60 subunits and $T=3$ capsids, consisting of 180 subunits were formed.

\section{Pyruvate dehydrogenase complex}

Pyruvate dehydrogenase (PDH) multi-enzyme complexes of icosahedral symmetry are found in the mitochondria of eukaryotes and Gram-positive bacteria. ${ }^{114}$ These PDHcomplexes contain a dihydrolipoyl acetyltransferase (E2), a pyruvate decarboxylase (E1), a dihydrolipoyl dehydrogenase (E3), and, in the case of the mammalian enzymes, an E3-binding protein and regulatory kinases and phosphatases. The E2 component of this complex consists of a $28 \mathrm{kDa}$ catalytic domain, a $4 \mathrm{kDa}$ peripheral subunit-binding domain (PSBD) and a $9 \mathrm{kDa}$ lipoyl domain, which are connected by long stretches of polypeptide chain thought to be largely flexible in conformation. ${ }^{115}$ In a native PDH-complex, 60 copies of E2 self-assemble through interactions of their catalytic domains to form an icosahedral structure, to which $42-48$ copies of an $\alpha_{2} \beta_{2}$-E1 (153 $\mathrm{kDa})$ and 6-12 copies of a homodimeric E3 (100 kDa) bind tightly around the outside (Fig. 19). ${ }^{114}$

The inner icosahedral shell formed by the E2 subunits is approximately $24 \mathrm{~nm}$ in diameter and has 12 openings of $5 \mathrm{~nm}$ each. Since this enzyme complex is derived from a thermophilic organism, the association of the subunits into the multi-enzyme complex has been shown to be stable at high temperatures. ${ }^{116}$

Domingo et al. showed that it is possible to display antibody epitopes and EGFP on the outer surface of E2. ${ }^{117,118}$ This was achieved by replacing the PSDB and lipoyl domains linked to the E2 catalytic domain with either antibody epitopes or EGFP. The resulting fusion protein was able to assemble, thus displaying the epitopes and EGFP on the exterior of the complex. A few years later, Dalmau et al. investigated the potential of the E2 scaffold as a potential molecular carrier. ${ }^{119}$ In this work, the authors first synthesized a truncated gene encoding for E2 which was optimized for expression in E. coli. By mutation of the E2 encoding gene, selected amino acids were changed to amino acids
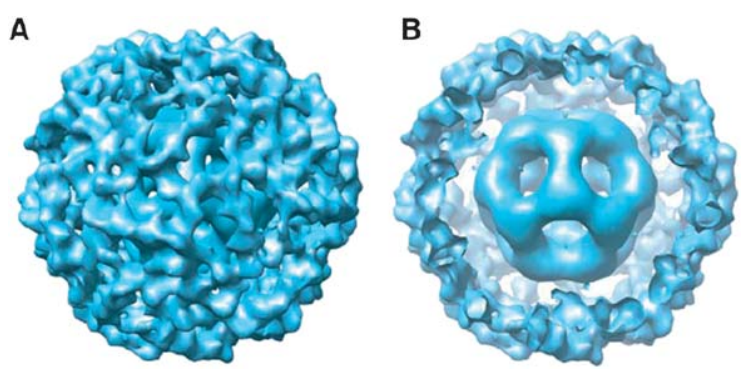

Fig. 19 Schematic representations of the PDH-complex. (A) Surface representation of a three-dimensional model of an E2E3 complex, viewed along the 3 -fold axis of symmetry. (B) Same representation with a portion of the outer protein shell removed to visualize the inner E2-core. ${ }^{114}$ Reproduced with permission from ASBMB, see ref. 114.

with different physicochemical properties. Even after 120 mutations, the E2 complex still assembled into a dodecahedral structure with high thermal stability. The cysteine mutants of the scaffold were used to couple two fluorescent dyes, leading to its sequestration into the inner cavity of the E2-complex. TEM images showed that even after covalent encapsulation of the molecules in the inner cavity, the dodecahedral structure remained intact.

In this work, the authors describe a clear method to encapsulate foreign cargos in the cavity of the E2-complex. Their work can be regarded as a tool for the encapsulation of enzymes in the future.

\section{Concluding remarks}

In this review different examples of protein-based nanoreactors have been described. These self-assembled structures all exist in nature and can be chemically or genetically modified for the creation of nanoparticles, or nanocatalysts.

Protein cages from ferritin and ferritin-like proteins were the first bio-nanoreactors used for biomineralization reactions in a constrained environment. A very wide range of inorganic materials has been successfully synthesized within these cagestructures. A few years later, the use of viral cages for the same purposes became of great interest. Viral cages offer a similar constrained reaction environment but exist in a wider range of shapes and structures, for example the rod-shaped TMV and the icosahedral CCMV, which enables the formation of nanoparticles of more diverse sizes and shapes. Also, some of the viruses are known to be able to change their morphology upon exposure to a changing environment, which increases the possibilities even further. CCMV and TMV are now commonly used to nucleate minerals in their cavities, but this field is still young and it is very probable that in the future more applications for viral capsids will be developed, like MRI contrast imaging agents.

As mentioned before, one of the main advantages of using protein cages for the synthesis of nanoparticles is the monodispersity of the resulting particles. This is a direct result of the monodispersity of the protein cages themselves, as the nanoparticles grow until they fill the interior of the capsid. It would be expected therefore, that all nanoparticles formed in one type of protein cage would be of the same size. This is, however, not 
always the case, as is shown by the different sizes of the nanoparticles formed within the CCMV capsid. Although all nanoparticles of the same type are very monodisperse, there is a considerable size difference between different types of nanoparticles formed within the CCMV capsid, ranging from vanadate particles of $15 \mathrm{~nm}$ in diameter, ${ }^{69}$ to iron particles of $24 \mathrm{~nm}$ in diameter. ${ }^{13}$ This can be due to the presence of a 'void space' between the capsid shell and the nanoparticle. It is probable that the size of this space is influenced by the encapsulated material and possibly by the reaction conditions.

The confined space of protein cages has thus far mainly been used for biomineralization reactions. The metal nucleation sites have also been used to immobilize small inorganic catalysts on the interior, which resulted in a nanoreactor that could initiate polymerization of monomers inside the cage. ${ }^{33}$ The application of protein cages for the immobilization of enzymes and the study of enzymatic reactions has great potential, especially since the discovery of bacterial microcompartments shows that nature also uses protein cages for the encapsulation of enzymes to create mini-organelles. Thus far only a few groups have published methods to encapsulate proteins in protein cages ${ }^{10-12,83,108}$ and even fewer have reported on enzymatic reactions inside the cages ${ }^{\mathbf{8}, 120}$ but the future for this field is very promising. A large part of the research described in this review is therefore devoted to this subject.

\section{Acknowledgements}

The Chemical Council of the Netherlands' National Science Foundation (NWO-CW), the European Science Foundation (ESF) and the Royal Netherlands Academy of Arts and Sciences (KNAW) are acknowledged for financial support.

\section{References}

1 A. de la Escosura, R. J. M. Nolte and J. Cornelissen, J. Mater. Chem., 2009, 19, 2274-2278.

2 Q. Chen, H. Schonherr and G. J. Vancso, Small, 2009, 5, 1436-1445.

3 D. M. Vriezema, M. C. Aragones, J. Elemans, J. Cornelissen, A. E. Rowan and R. J. M. Nolte, Chem. Rev., 2005, 105, 1445-1489.

4 S. F. M. van Dongen, M. Nallani, J. Cornelissen, R. J. M. Nolte and J. C. M. van Hest, Chem.-Eur. J., 2009, 15, 1107-1114.

5 P. Walde and S. Ichikawa, Biomol. Eng., 2001, 18, 143-177.

6 S. M. Kuiper, M. Nallani, D. M. Vriezema, J. Cornelissen, J. C. M. van Hest, R. J. M. Nolte and A. E. Rowan, Org. Biomol. Chem., 2008, 6, 4315-4318.

7 W. Ha, X. W. Meng, Q. Li, M. M. Fan, S. L. Peng, L. S. Ding, X. Tian, S. Zhang and B. J. Li, Soft Matter, 2010, 6, 1405-1408.

8 M. Comellas-Aragones, H. Engelkamp, V. I. Claessen, N. Sommerdijk, A. E. Rowan, P. C. M. Christianen, J. C. Maan, B. J. M. Verduin, J. Cornelissen and R. J. M. Nolte, Nat. Nanotechnol., 2007, 2, 635-639.

9 L. B. Kong, A. C. Siva, L. H. Rome and P. L. Stewart, Structure, 1999, 7, 371-379.

10 F. P. Seebeck, K. J. Woycechowsky, W. Zhuang, J. P. Rabe and D. Hilvert, J. Am. Chem. Soc., 2006, 128, 4516-4517.

11 C. G. Fan, S. Q. Cheng, Y. Liu, C. M. Escobar, C. S. Crowley, R. E. Jefferson, T. O. Yeates and T. A. Bobik, Proc. Natl. Acad. Sci. U. S. A., 2010, 107, 7509-7514.

12 I. J. Minten, V. I. Claessen, K. Blank, A. E. Rowan, R. J. M. Nolte and J. J. L. M. Cornelissen, Chem. Sci., 2011, 2, 358.

13 T. Douglas, E. Strable, D. Willits, A. Aitouchen, M. Libera and M. Young, Adv. Mater., 2002, 14, 415-418.

14 T. Ueno, M. Suzuki, T. Goto, T. Matsumoto, K. Nagayama and Y. Watanabe, Angew. Chem., Int. Ed., 2004, 43, 2527-2530.
15 M. Allen, D. Willits, J. Mosolf, M. Young and T. Douglas, $A d v$. Mater., 2002, 14, 1562-1565.

16 E. C. Theil, Annu. Rev. Biochem., 1987, 56, 289-315.

17 N. D. Chasteen and P. M. Harrison, J. Struct. Biol., 1999, 126, 182-194.

18 M. Uchida, M. T. Klem, M. Allen, P. Suci, M. Flenniken, E. Gillitzer, Z. Varpness, L. O. Liepold, M. Young and T. Douglas, Adv. Mater., 2007, 19, 1025-1042.

19 P. M. Harrison, F. A. Fischbac, T. G. Hoy and G. H. Haggis, Nature, 1967, 216, 1188-1190.

20 P. M. Harrison, S. C. Andrews, P. J. Artymiuk, G. C. Ford, J. R. Guest, J. Hirzmann, D. M. Lawson, J. C. Livingstone, J. M. A. Smith, A. Treffry and S. J. Yewdall, Adv. Inorg. Chem., 1991, 36, 449-486.

21 N. D. Chasteen, in Metal Ions in Biological Systems, Marcel Dekker, New York, 1998, vol. 35, pp. 479-514.

22 F. C. Meldrum, V. J. Wade, D. L. Nimmo, B. R. Heywood and S. Mann, Nature, 1991, 349, 684-687.

23 S. Mann and F. C. Meldrum, Adv. Mater., 1991, 3, 316-318.

24 S. Mann, D. D. Archibald, J. M. Didymus, T. Douglas, B. R. Heywood, F. C. Meldrum and N. J. Reeves, Science, 1993, 261, 1286-1292.

25 T. Douglas, D. P. E. Dickson, S. Betteridge, J. Charnock, C. D. Garner and S. Mann, Science, 1995, 269, 54-57.

26 F. C. Meldrum, T. Douglas, S. Levi, P. Arosio and S. Mann, J. Inorg. Biochem., 1995, 58, 59-68.

27 M. Li, C. Viravaidya and S. Mann, Small, 2007, 3, 1477-1481.

28 H. Yoshimura, Colloids Surf., A, 2006, 282, 464 470.

29 R. Tsukamoto, K. Iwahor, M. Muraoka and I. Yamashita, Bull. Chem. Soc. Jpn., 2005, 78, 2075-2081.

30 M. Okuda, K. Iwahori, I. Yamashita and H. Yoshimura, Biotechnol. Bioeng., 2003, 84, 187-194.

31 I. Kim, H. A. Hosein, D. R. Strongin and T. Douglas, Chem. Mater., 2002, 14, 4874-4879.

32 D. Ensign, M. Young and T. Douglas, Inorg. Chem., 2004, 43, 34413446.

33 S. Abe, K. Hirata, T. Ueno, K. Morino, N. Shimizu, M. Yamamoto, M. Takata, E. Yashima and Y. Watanabe, J. Am. Chem. Soc., 2009, 131, 6958-6960.

34 O. Kasyutich, A. Ilari, A. Fiorillo, D. Tatchev, A. Hoell and P. Ceci, J. Am. Chem. Soc., 2010, 132, 3621-3627.

35 R. M. Kramer, C. Li, D. C. Carter, M. O. Stone and R. R. Naik, J. Am. Chem. Soc., 2004, 126, 13282-13286.

36 T. Douglas and D. R. Ripoll, Protein Sci., 1998, 7, 1083-1091.

37 A. Giorgi, G. Mignogna, G. Bellapadrona, M. Gattoni, R. Chiaraluce, V. Consalvi, E. Chiancone and S. Stefanini, Arch. Biochem. Biophys., 2008, 478, 69-74.

38 T. Ueno, M. Abe, K. Hirata, S. Abe, M. Suzuki, N. Shimizu, M. Yamamoto, M. Takata and Y. Watanabe, J. Am. Chem. Soc., 2009, 131, 5094-5100.

39 S. Aime, L. Frullano and S. G. Crich, Angew. Chem., Int. Ed., 2002, 41, 1017-1019.

40 J. W. M. Bulte, T. Douglas, S. Mann, R. B. Frankel, B. M. Moskowitz, R. A. Brooks, C. D. Baumgarner, J. Vymazal and J. A. Frank, Invest. Radiol., 1994, 29, S214-S216.

41 F. C. Meldrum, B. R. Heywood and S. Mann, Science, 1992, 257, $522-523$.

42 K. K. W. Wong, T. Douglas, S. Gider, D. D. Awschalom and S. Mann, Chem. Mater., 1998, 10, 279-285.

43 M. T. Klem, D. A. Resnick, K. Gilmore, M. Young, Y. U. Idzerda and T. Douglas, J. Am. Chem. Soc., 2007, 129, 197-201.

44 G. H. Zhao, P. Ceci, A. Ilari, L. Giangiacomo, T. M. Laue, E. Chiancone and N. D. Chasteen, J. Biol. Chem., 2002, 277, 27689-27696.

45 E. Chiancone and P. Ceci, Biochim. Biophys. Acta, Gen. Subj., 2010, 1800, 798-805.

46 X. K. Yang, E. Chiancone, S. Stefanini, A. Ilari and N. D. Chasteen, Biochem. J., 2000, 349, 783-786.

47 R. A. Grant, D. J. Filman, S. E. Finkel, R. Kolter and J. M. Hogle, Nat. Struct. Biol., 1998, 5, 294-303.

48 M. Bozzi, G. Mignogna, S. Stefanini, D. Barra, C. Longhi, P. Valenti and E. Chiancone, J. Biol. Chem., 1997, 272, 3259-3265.

49 A. Ilari, S. Stefanini, E. Chiancone and D. Tsernoglou, Nat. Struct. Biol., 2000, 7, 38-43.

50 M. Allen, D. Willits, M. Young and T. Douglas, Inorg. Chem., 2003, 42, 6300-6305. 
51 K. Iwahori, T. Enomoto, H. Furusho, A. Miura, K. Nishio, Y. Mishima and I. Yamashita, Chem. Mater., 2007, 19, 3105-3111.

52 S. Kang, J. Lucon, Z. B. Varpness, L. Liepold, M. Uchida, D. Willits, M. Young and T. Douglas, Angew. Chem., Int. Ed., 2008, 47, 7845-7848.

53 S. Kang, C. C. Jolley, L. O. Liepold, M. Young and T. Douglas, Angew. Chem., Int. Ed., 2009, 48, 4772-4776.

54 J. Swift, W. A. Wehbi, B. D. Kelly, X. F. Stowell, J. G. Saven and I. J. Dmochowski, J. Am. Chem. Soc., 2006, 128, 6611-6619.

55 K. K. Kim, R. Kim and S. H. Kim, Nature, 1998, 394, 595-599.

56 L. O. Liepold, J. Revis, M. Allen, L. Oltrogge, M. Young and T. Douglas, Phys. Biol., 2005, 2, S166-S172.

57 M. L. Flenniken, D. A. Willits, S. Brumfield, M. J. Young and T. Douglas, Nano Lett., 2003, 3, 1573-1576.

58 M. L. Flenniken, L. O. Liepold, B. E. Crowley, D. A. Willits, M. J. Young and T. Douglas, Chem. Commun., 2005, 447-449.

59 Z. Varpness, J. W. Peters, M. Young and T. Douglas, Nano Lett., 2005, 5, 2306-2309.

60 M. J. Abedin, L. Liepold, P. Suci, M. Young and T. Douglas, J. Am. Chem. Soc., 2009, 131, 4346-4354.

61 R. A. McMillan, J. Howard, N. J. Zaluzec, H. K. Kagawa, R. Mogul, Y. F. Li, C. D. Paavola and J. D. Trent, J. Am. Chem. Soc., 2005, 127, 2800-2801.

62 K. Braig, Z. Otwinowski, R. Hegde, D. C. Boisvert, A. Joachimiak, A. L. Horwich and P. B. Sigler, Nature, 1994, 371, 578-586.

63 D. Ishii, K. Kinbara, Y. Ishida, N. Ishii, M. Okochi, M. Yohda and T. Aida, Nature, 2003, 423, 628-632.

64 T. Douglas and M. Young, Science, 2006, 312, 873-875.

65 S. E. Aniagyei, C. DuFort, C. C. Kao and B. Dragnea, J. Mater. Chem., 2008, 18, 3763-3774.

66 M. Young, D. Willits, M. Uchida and T. Douglas, Annu. Rev. Phytopathol., 2008, 46, 361-384.

67 J. E. Johnson and J. A. Speir, J. Mol. Biol., 1997, 269, 665-675.

68 J. A. Speir, S. Munshi, G. J. Wang, T. S. Baker and J. E. Johnson, Structure, 1995, 3, 63-78.

69 T. Douglas and M. Young, Nature, 1998, 393, 152-155.

70 M. T. Klem, M. Young and T. Douglas, J. Mater. Chem., 2008, 18, 3821-3823.

71 A. de la Escosura, M. Verwegen, F. D. Sikkema, M. ComellasAragones, A. Kirilyuk, T. Rasing, R. J. M. Nolte and J. Cornelissen, Chem. Commun., 2008, 1542-1544.

72 C. M. Liu, S. H. Chung, Q. L. Jin, A. Sutton, F. N. Yan, A. Hoffmann, B. K. Kay, S. D. Bader, L. Makowski and L. H. Chen, J. Magn. Magn. Mater., 2006, 302, 47-51.

73 J. M. Hooker, E. W. Kovacs and M. B. Francis, J. Am. Chem. Soc., 2004, 126, 3718-3719.

74 J. M. Hooker, A. Datta, M. Botta, K. N. Raymond and M. B. Francis, Nano Lett., 2007, 7, 2207-2210.

75 M. Knez, A. M. Bittner, F. Boes, C. Wege, H. Jeske, E. Maiss and K. Kern, Nano Lett., 2003, 3, 1079-1082.

76 M. Knez, M. Sumser, A. M. Bittner, C. Wege, H. Jeske, T. P. Martin and K. Kern, Adv. Funct. Mater., 2004, 14, 116-124.

77 S. Balci, A. M. Bittner, K. Hahn, C. Scheu, M. Knez, A. Kadri, C. Wege, H. Jeske and K. Kern, Electrochim. Acta, 2006, 51, $6251-6257$.

78 R. Tsukamoto, M. Muraoka, M. Seki, H. Tabata and I. Yamashita, Chem. Mater., 2007, 19, 2389-2391.

79 Y. J. Lee, H. Yi, W. J. Kim, K. Kang, D. S. Yun, M. S. Strano, G. Ceder and A. M. Belcher, Science, 2009, 324, 1051-1055.

80 E. Dujardin, C. Peet, G. Stubbs, J. N. Culver and S. Mann, Nano Lett., 2003, 3, 413-417.

81 T. L. Schlick, Z. B. Ding, E. W. Kovacs and M. B. Francis, J. Am. Chem. Soc., 2005, 127, 3718-3723.

82 S. W. Lee, C. B. Mao, C. E. Flynn and A. M. Belcher, Science, 2002, 296, 892-895.

83 T. Inoue, M. A. Kawano, R. U. Takahashi, H. Tsukarnoto, T. Enornoto, T. Imai, K. Kataoka and H. Handa, J. Biotechnol., 2008, 134, 181-192.

84 I. J. Minten, L. J. A. Hendriks, R. J. M. Nolte and J. J. L. M. Cornelissen, J. Am. Chem. Soc., 2009, 131, 1777117773.

85 R. L. Garcea and L. Gissmann, Curr. Opin. Biotechnol., 2004, 15, 513-517.

86 R. C. Liddington, Y. Yan, J. Moulai, R. Sahli, T. L. Benjamin and S. C. Harrison, Nature, 1991, 354, 278-284.
87 T. Stehle, S. J. Gamblin, Y. W. Yan and S. C. Harrison, Structure, 1996, 4, 165-182.

88 S. N. Kanesashi, K. Ishizu, M. Kawano, S. Han, S. Tomita, H. Watanabe, K. Kataoka and K. Handa, J. Gen. Virol., 2003, 84, $1899-1905$.

89 M. Kawano, T. Inoue, H. Tsukamoto, T. Takaya, T. Enomoto, R. Takahashi, N. Yokoyama, N. Yamamoto, A. Nakanishi, T. Imai, T. Wada, K. Kataoka and H. Handa, J. Biol. Chem., 2006, 281, 10164-10173.

90 L. Montross, S. Watkins, R. B. Moreland, H. Mamon, D. L. D. Caspar and R. L. Garcea, J. Virol., 1991, 65, 4991-4998.

91 A. Abbing, U. K. Blaschke, S. Grein, M. Kretschmar, C. M. B. Stark, M. J. W. Thies, J. Walter, M. Weigand, D. C. Woith, J. Hess and C. O. A. Reiser, J. Biol. Chem., 2004, 279, 27410-27421.

92 E. Boura, D. Liebl, R. Spisek, J. Fric, M. Marek, J. Stokrova, V. Holan and J. Forstova, FEBS Lett., 2005, 579, 6549-6558.

93 N. Carette, H. Engelkamp, E. Akpa, S. J. Pierre, N. R. Cameron, P. C. M. Christianen, J. C. Maan, J. C. Thies, R. Weberskirch, A. E. Rowan, R. J. M. Nolte, T. Michon and J. C. M. Van Hest, Nat. Nanotechnol., 2007, 2, 226-229.

94 M. Sutter, D. Boehringer, S. Gutmann, S. Guenther, D. Prangishvili, M. J. Loessner, K. O. Stetter, E. Weber-Ban and N. Ban, Nat. Struct. Mol. Biol., 2008, 15, 939-947.

95 G. C. Cannon, C. E. Bradburne, H. C. Aldrich, S. H. Baker, S. Heinhorst and J. M. Shively, Appl. Environ. Microbiol., 2001, 67, 5351-5361.

96 C. A. Kerfeld, M. R. Sawaya, S. Tanaka, C. V. Nguyen, M. Phillips, M. Beeby and T. O. Yeates, Science, 2005, 309, 936-938.

97 S. Tanaka, C. A. Kerfeld, M. R. Sawaya, F. Cai, S. Heinhorst, G. C. Cannon and T. O. Yeates, Science, 2008, 319, 1083-1086.

98 G. D. Havemann, E. M. Sampson and T. A. Bobik, J. Bacteriol., 2002, 184, 1253-1261.

99 E. Kofoid, C. Rappleye, I. Stojiljkovic and J. Roth, J. Bacteriol., 1999, 181, 5317-5329.

100 D. H. Anderson, V. A. Kickhoefer, S. A. Sievers, L. H. Rome and D. Eisenberg, PLoS Biol., 2007, 5, 2661-2670.

101 K. Ritsert, R. Huber, D. Turk, R. Ladenstein, K. Schmidtbase and A. Bacher, J. Mol. Biol., 1995, 253, 151-167.

102 S. Jenni, M. Leibundgut, D. Boehringer, C. Frick, B. Mikolasek and N. Ban, Science, 2007, 316, 254-261.

103 A. Aevarsson, K. Seger, S. Turley, J. R. Sokatch and W. G. J. Hol, Nat. Struct. Biol., 1999, 6, 785-792.

104 T. A. Bobik, G. D. Havemann, R. J. Busch, D. S. Williams and H. C. Aldrich, J. Bacteriol., 1999, 181, 5967-5975.

105 L. B. Kong, A. C. Siva, V. A. Kickhoefer, L. H. Rome and P. L. Stewart, RNA, 2000, 6, 890-900.

106 L. E. Goldsmith, M. Pupols, V. A. Kickhoefer, L. H. Rome and H. G. Monbouquette, ACS Nano, 2009, 3, 3175-3183.

107 C. Y. Lai, C. M. Wiethoff, V. A. Kickhoefer, L. H. Rome and G. R. Nemerow, ACS Nano, 2009, 3, 691-699.

108 V. A. Kickhoefer, Y. Garcia, Y. Mikyas, E. Johansson, J. C. Zhou, S. Raval-Fernandes, P. Minoofar, J. I. Zink, B. Dunn, P. L. Stewart and L. H. Rome, Proc. Natl. Acad. Sci. U. S. A., 2005, 102, 43484352.

109 B. C. Ng, M. Yu, A. Gopal, L. H. Rome, H. G. Monbouquette and S. H. Tolbert, Nano Lett., 2008, 8, 3503-3509.

110 R. Ladenstein, M. Schneider, R. Huber, H. D. Bartunik, K. Wilson, K. Schott and A. Bacher, J. Mol. Biol., 1988, 203, 1045-1070.

111 R. Ladenstein, A. Bacher and R. Huber, J. Mol. Biol., 1987, 195, $751-753$.

112 K. Schott, R. Ladenstein, A. Konig and A. Bacher, J. Biol. Chem., 1990, 265, 12686-12689.

113 W. Shenton, S. Mann, H. Colfen, A. Bacher and M. Fischer, Angew. Chem., Int. Ed., 2001, 40, 442-445.

114 J. L. S. Milne, X. W. Wu, M. J. Borgnia, J. S. Lengyel, B. R. Brooks, D. Shi, R. N. Perham and S. Subramaniam, J. Biol. Chem., 2006, 281, 4364-4370.

115 J. L. S. Milne, D. Shi, P. B. Rosenthal, J. S. Sunshine, G. J. Domingo, X. W. Wu, B. R. Brooks, R. N. Perham, R. Henderson and S. Subramaniam, EMBO J., 2002, 21, 5587-5598.

116 H. I. Jung, A. Cooper and R. N. Perham, Biochemistry, 2002, 41, 10446-10453.

117 G. J. Domingo, S. Orru and R. N. Perham, J. Mol. Biol., 2001, 305, 259-267. 
118 G. J. Domingo, A. Caivano, R. Sartorius, P. Barba, M. Backstrom, D. Piatier-Tonneau, J. Guardiola, P. De Berardinis and R. N. Perham, Vaccine, 2003, 21, 1502-1509.

119 M. Dalmau, S. Lim, H. C. Chen, C. Ruiz and S. W. Wang, Biotechnol. Bioeng., 2008, 101, 654-664.
120 Note: the fast emergence of this field is further emphasized by recent reports from the groups of Finn and Hilvert on enzyme encapsulation in protein cages; J. D. Fiedler, S. D. Brown, J. L. Lau and M. G. Finn, Angew. Chem., Int. Ed., 2010, 49, 9648, and B. Woersdoerfer, K. J. Woycechowsky and D. Hilvert, Science, 2011, 331, 589. 